\title{
Market Analysis for Urban Mining of Phosphogypsum
}

\author{
Kathrin Layr and Philipp Hartlieb \\ Mining Engineering and Mineral Economics, Department Mineral Resources Engineering, Montanuniversität \\ Leoben, Leoben, Austria
}

Received March 29, 2019; accepted April 2, 2019; published online April 18, 2019

\begin{abstract}
Phosphogypsum (PG) is a by-product of the phosphorus fertilizer production. Due to its radionuclide and heavy metal content, PG tailings pose both environmental and health risks. On the other side, gypsum is a valuable raw material, primarily used in construction. Hence, a study was conducted to analyze the gypsum market, both demand and supply, focusing on Eastern and Southeastern Europe (ESEE).

The reduction of coal-fired power plants in Europe causes a decline of gypsum produced by flue-gas desulfurization and simultaneous increase in "dry" construction methods as well as soil salinization in Europe. A decrease in supply and increase in demand results in a growing market for gypsum in years to come. Impurities call for primary treatment of PG.
\end{abstract}

Keywords: Urban Mining, Phosphogypsum, Market Analysis

Marktanalyse für Urban Mining von Phosphorgipshalden

Zusammenfassung: Phosphorgips (PG) ist ein Nebenprodukt der Phosphordüngerproduktion. Da er Radionuklide und Schwermetalle enthält, stellt er ein potenzielles Umwelt- und Gesundheitsrisiko dar. Gips ist gleichzeitig ein Mineral, das insbesondere als Baurohstoff verwendet wird. Um die wirtschaftliche Wiederverwertung von Phosphorgips zu untersuchen, wurde eine Gipsmarktanalyse mit Fokus auf Ost- und Südosteuropa (ESEE) durchgeführt.

Die Reduktion des Kohlestromanteils in Europa hat ein Sinken der Rehagipsproduktion zur Folge. Gleichzeitig steigt der Anteil "trockener" Baumethoden und die Versalzung europäischer Böden, steigende Nachfrage in den nächsten Jahren kann erwartet werden. Verunreinigungen können eine Vorbehandlung des PG notwendig machen.

\section{Dr. P. Hartlieb (殴)}

Mining Engineering and Mineral Economics, Department Mineral Resources Engineering,

Montanuniversität Leoben

Franz-Josef-Straße 18,

8700 Leoben, Austria

Philipp.hartlieb@unileoben.ac.at
Schlüsselwörter: Urban Mining, Phosphorgips, Marktanalyse

\section{Introduction}

Phosphoric acid for phosphorus fertilizers is produced during the "wet process", whereby the ground phosphate rock is treated with sulfuric acid, with gypsum as a by-product

$$
\begin{aligned}
& \mathrm{Ca}_{10}\left(\mathrm{PO}_{4}\right)_{6} \mathrm{~F}_{2}+10 \mathrm{H}_{2} \mathrm{SO}_{4}+20 \mathrm{H}_{2} \mathrm{O} \\
& \rightarrow 10 \mathrm{CaSO}_{4} \cdot 2 \mathrm{H}_{2} \mathrm{O}+6 \mathrm{H}_{3} \mathrm{PO}_{4}+2 \mathrm{HF}
\end{aligned}
$$

4 to 5 tons ( $t$ ) of phosphogypsum (PG) are produced per $t$ of phosphoric acid. Worldwide 100 to $280 \mathrm{Mt}$ of $\mathrm{PG}$ are produced annually [1]; with $175 \mathrm{Mt}$ of gypsum and anhydrite mined in 2016 [2]. Due to the content of radionuclides (mainly $U$ and $T h$ ) of phosphate rock, both phosphoric acid and $P G$ are slightly radioactive. $P G$ is therefore classified as TENORM (Technologically Enhanced Naturally Occurring Radioactive Material), most of the material is below legal critical values though. Only about $15 \%$ of the global PG is reused as soil stabilizer, agricultural fertilizer and in the cement industry [3]. Hence, large amounts of PG tailings are deposited worldwide, making reclamation of PG tailings a priority. To ensure the safe use of PG, DMT GmbH \& Co KG are developing a conveyor system capable of separating critical from uncritical material, thus guaranteeing for excellent quality PG for further industrial use. The majority of phosphate reserves are derived from sedimentary sources with higher radionuclide content than magmatic sources $[4,5]$. To investigate the reuse potential of $P G$ in order to reduce tailings, a market analysis with focus on ESEE was conducted.

\section{Supply and Consumption}

A comparison of European gypsum production, import and export data is given in Fig. 1. The PG production (based on fertilizer production) is expected to increase slightly, 


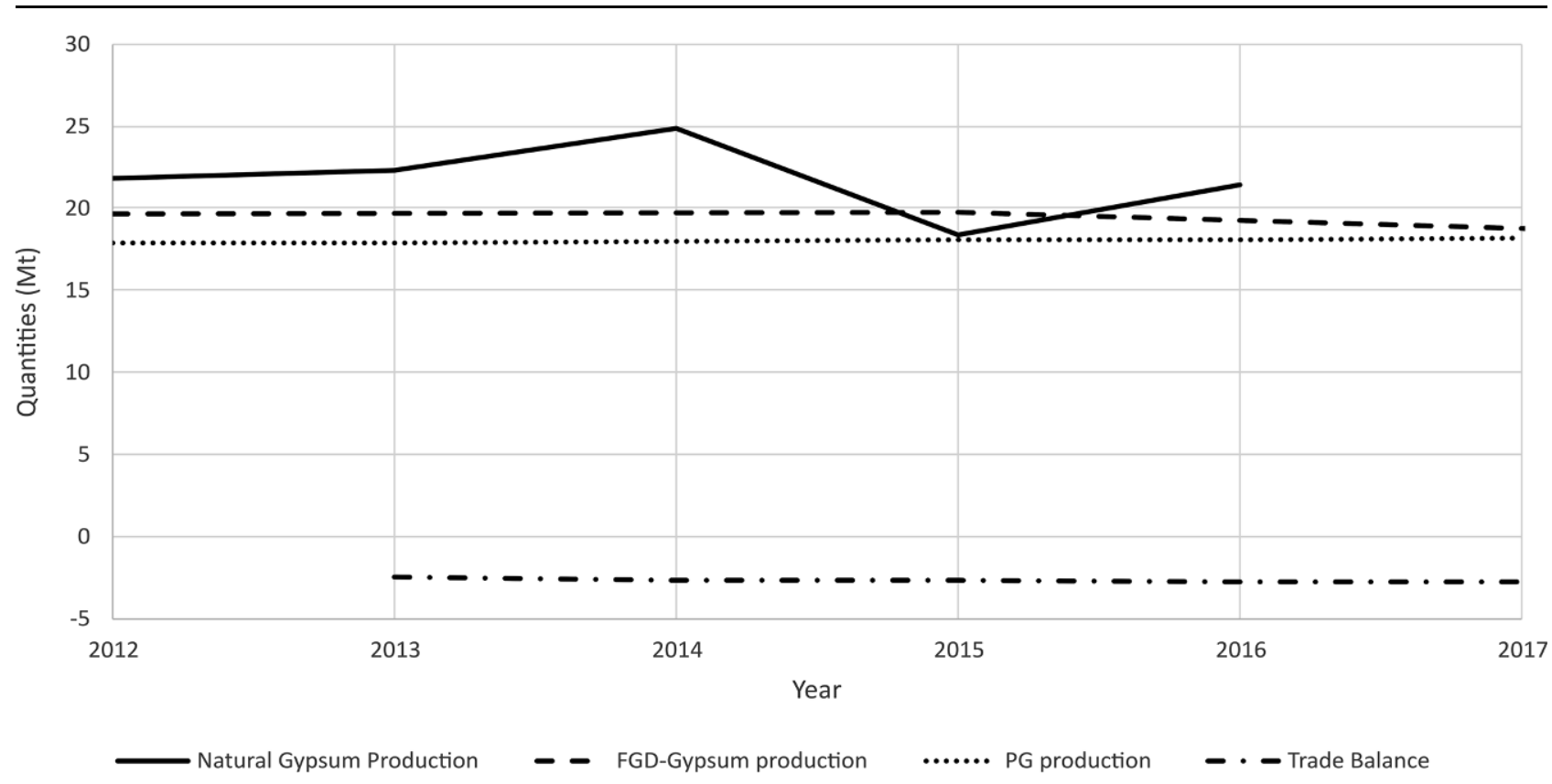

Fig. 1: Comparison of production of natural [2], PG [6] and FGD [7]; import and export data [4]

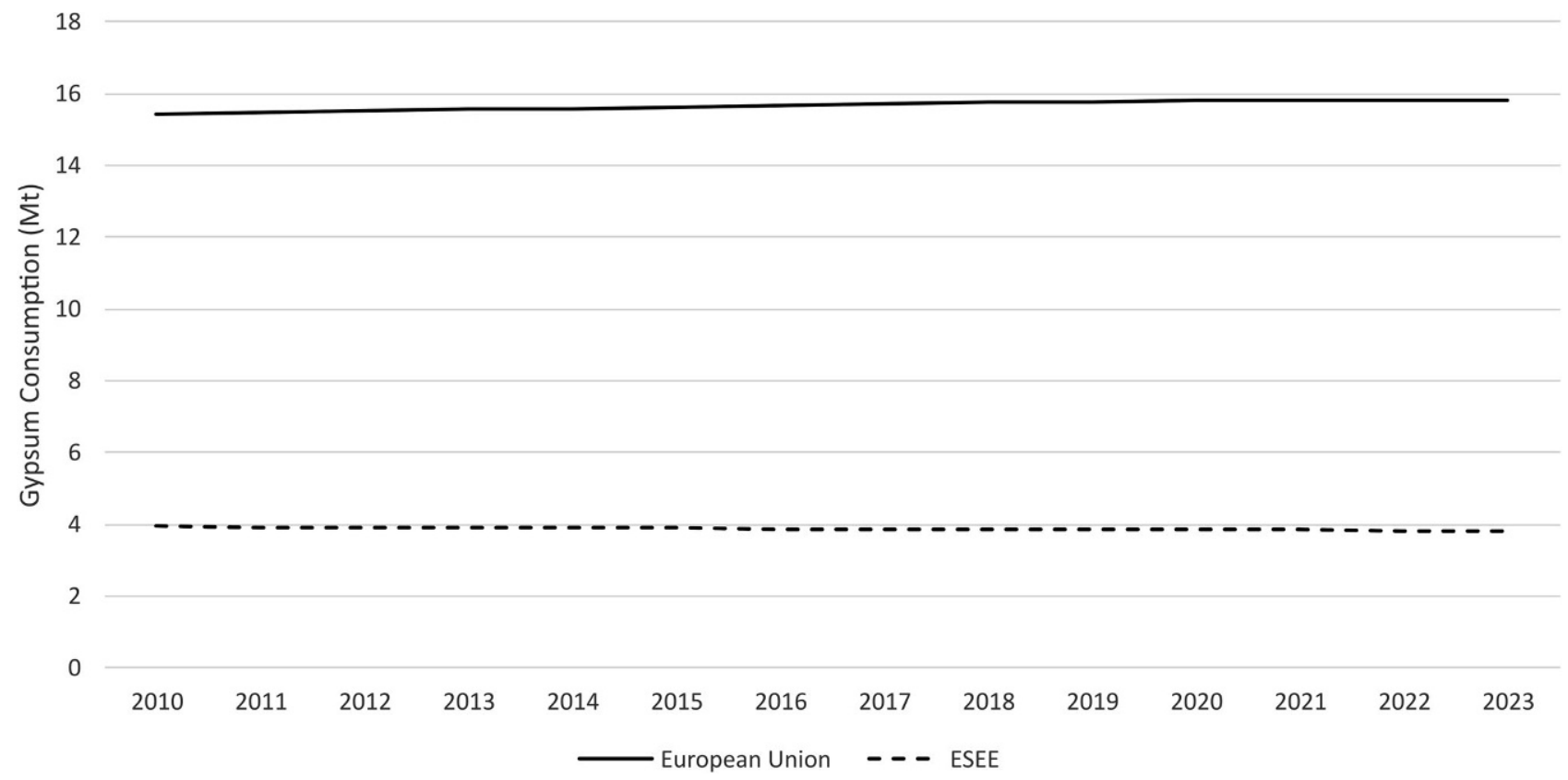

Fig. 2: Forecasted gypsum consumption of gypsum board industry

while the FGD- and natural gypsum production decreases slightly.

Gypsum applications include boards, plasters, mortars, cement, ceramics, bricks and soil stabilization applications. In this study only consumption potential for the major consumers boards, cement and agriculture were investigated.

The amount of gypsum used in boards in Europe and ESEE (see Fig. 2) was estimated based on PRODCOM data [8], and population forecasts from Eurostat. The consumption was assumed to be constant. Demand in ESEE decreases with the population, as opposed to overall Europe.
This effect may be compensated by the increase of dry construction methods in this area.

In cement, gypsum is used as a setting retarder [9], it also influences its mechanical properties [10]. Impurities in PG may further prolong setting time and decrease mechanical strength [3]. Though gypsum content in cement should be between 3.5 and $4.0 \%$ [11] , industry representatives consider $5 \%$ to be a more realistic value.

The consumption of gypsum in cement is lower than that of the board industry in Europe (see Fig. 3); in ESEE it surpasses the board industry, however [12]. 


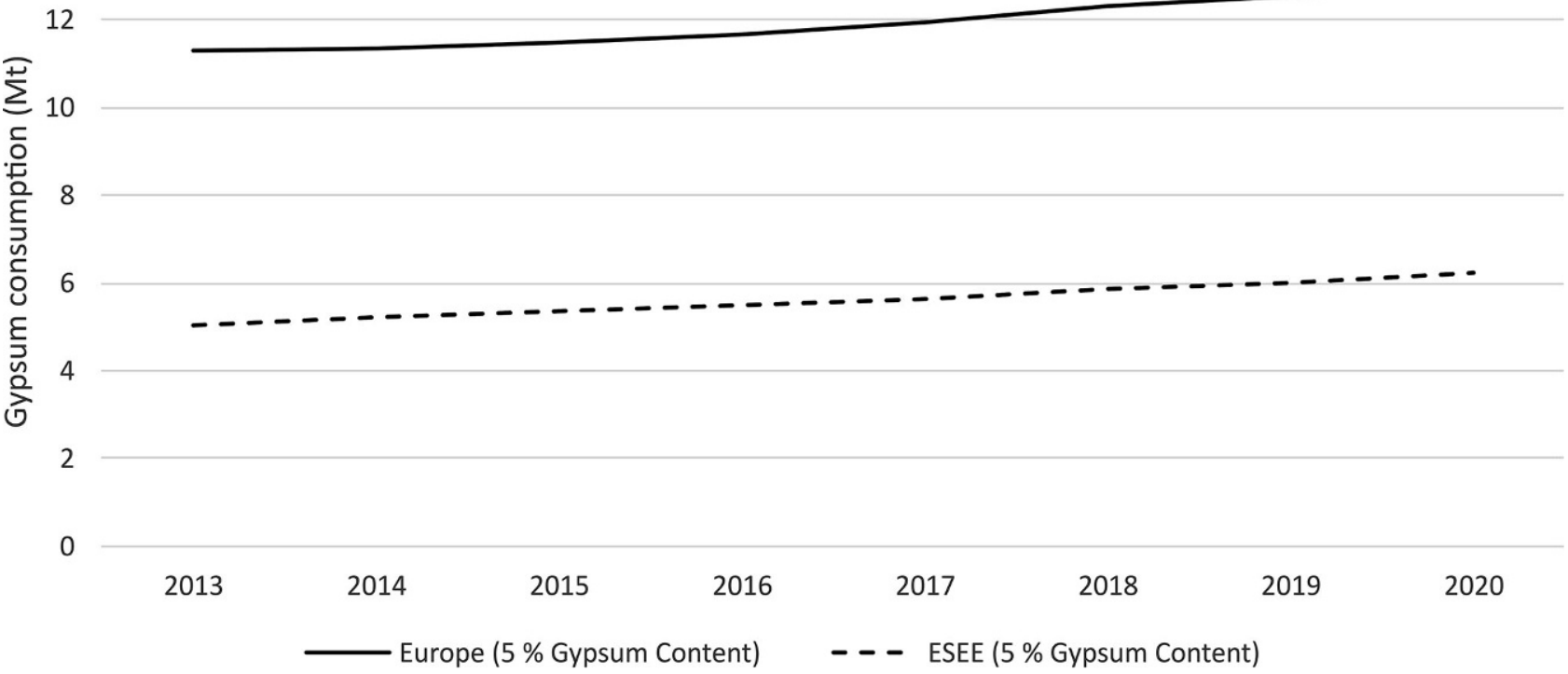

Fig. 3: Gypsum consumption of the cement industry [12]

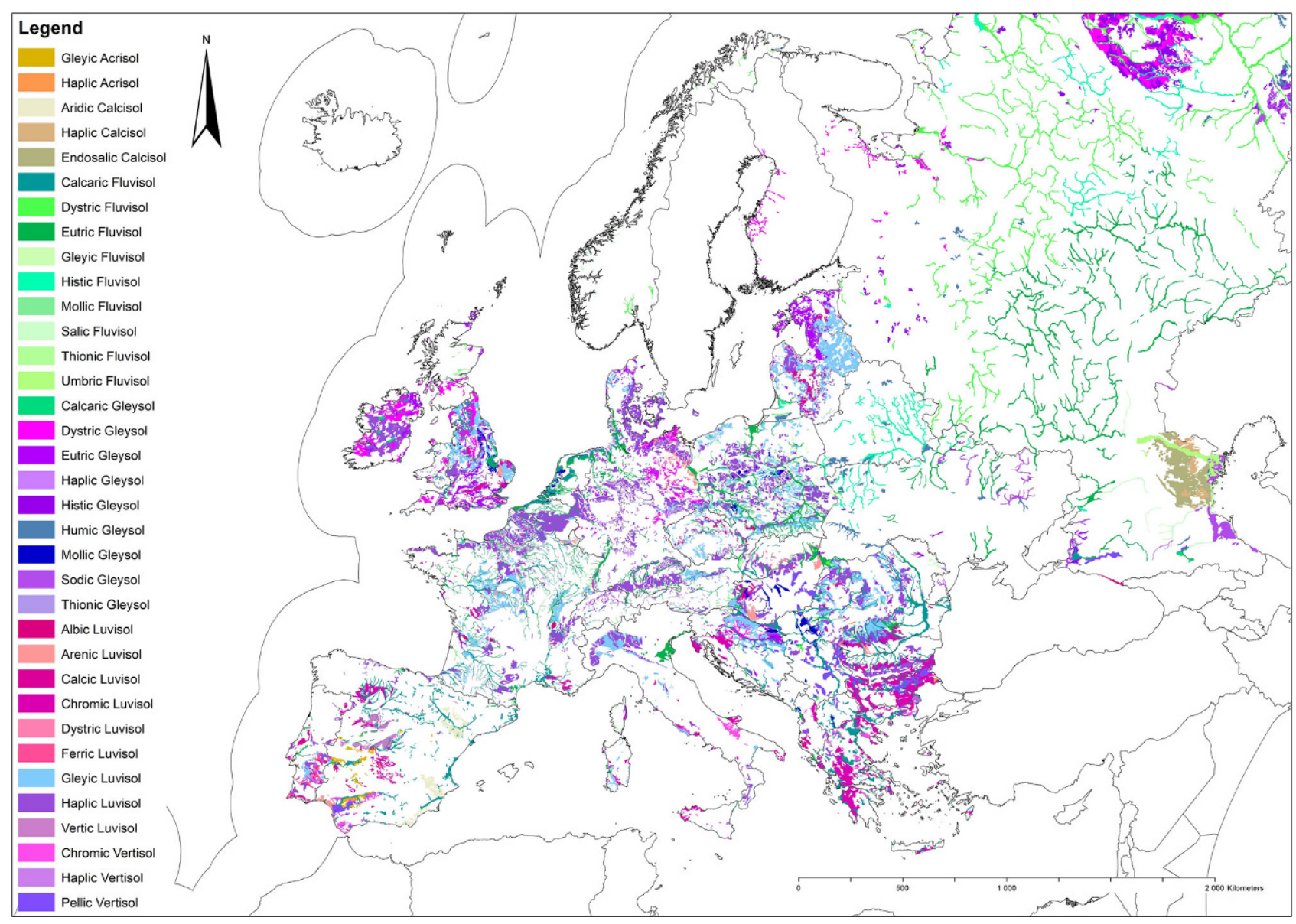

Fig. 4: Soils prone to salinization in Europe [21, 22] 


\begin{tabular}{|c|c|c|c|c|c|}
\hline & Quantity of gypsum & Euro & & ESEE & \\
\hline & $\mathrm{kg} \mathrm{m}^{-2} \mathrm{a}^{-1}$ & Mha & $\mathrm{Mta}^{-1}$ & Mha & $\mathrm{Mta}^{-1}$ \\
\hline Soils prone to salinization and used & 0.056 & 70.7 & 39.6 & 35.0 & 19.6 \\
\hline Salinity or sodicity cause limitation to agriculture & 0.5 & 4.9 & 24.5 & 1.8 & 9.0 \\
\hline
\end{tabular}

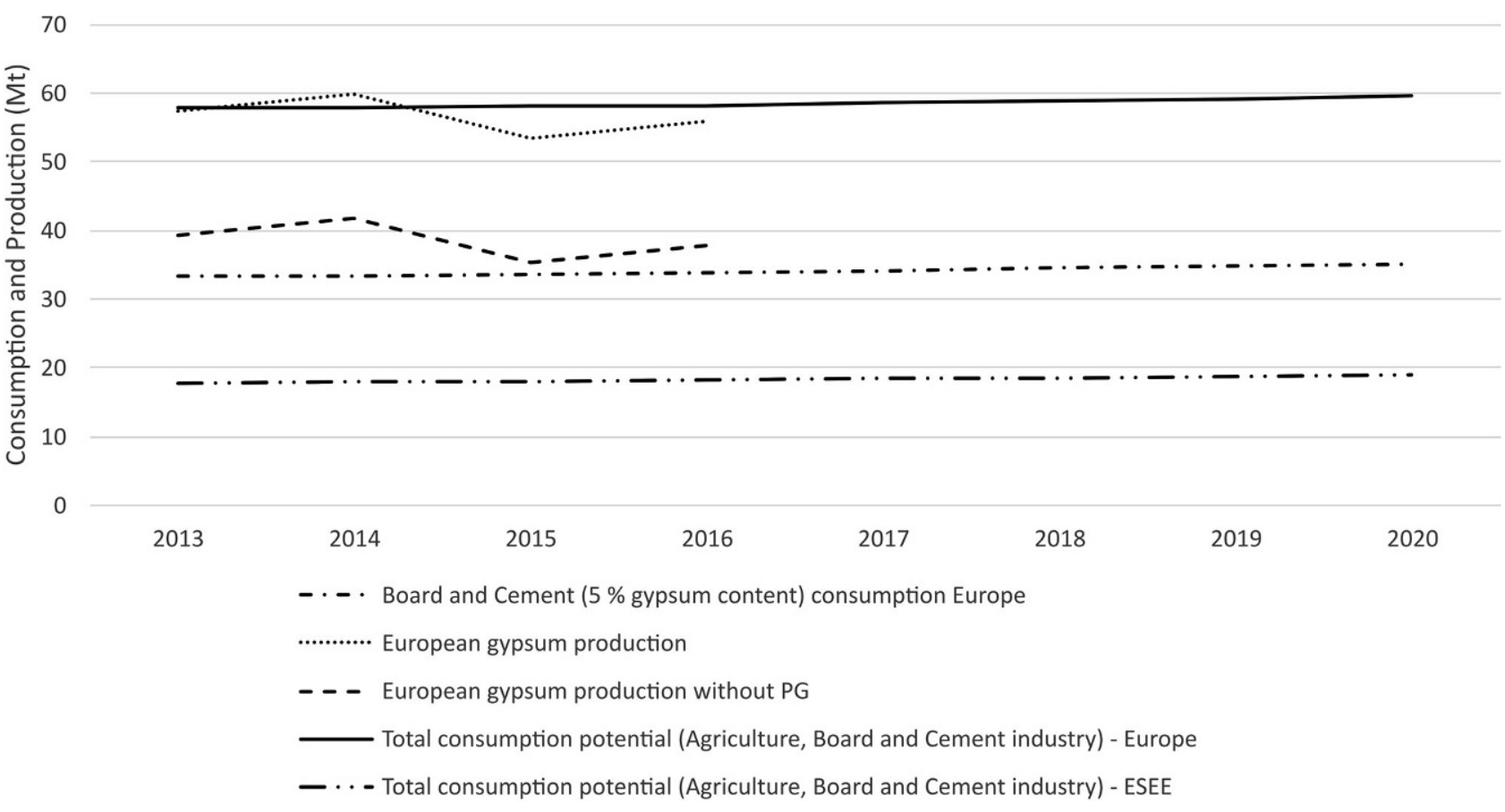

Fig. 5: Consumption by cement and board industry and agricultural potential in Europe

PG may be used as an amendment for acidic, sodic, calcareous and highly weathered soils [13]. Due to climate change, soil salinization is expected to increase [14, 15]. A gypsum application of $0.5 \mathrm{~kg} \mathrm{~m}^{-2} \mathrm{a}^{-1}$ for saline and sodic soils and $0.056 \mathrm{~kg} \mathrm{~m}^{-2} \mathrm{a}^{-1}$ for soils prone to salinization was chosen; suggested quantities are highly variable though [16-20]. The area affected by salinization was based on the European Soil Database ([21, 22]; Fig. 4 and Table 1).

The potential uptake in agriculture is vast (see Table 1), exceeding both cement and board industry. This estimation does not represent actual or estimated future consumption, however.

\section{Discussion and Conclusions}

The total gypsum consumption, with and without the agricultural potential, for ESEE and Europe is shown in Fig. 5. Gypsum consumption grows faster than PG production. Increase in gypsum board use per capita may steepen the rise in consumption. Due to other applications, the production exceeds the consumption. Total gypsum production significantly transcends the cement and board consumption, however. Including the potential use in agriculture outweighs this effect. The expected increase in soil salinization in Europe due to climate change could lead to a larger up- take for soil amendment. The natural gypsum production trend in Europe (see Fig. 5) as well as decrease in FGD gypsum production must be compensated, creating a market for alternative gypsum sources.

Due to the lack of data, an estimation of ESEE production is difficult. FGD gypsum production-depending on political will-can be expected to be stable, or even increase (for instance in Poland) in ESEE. An effect possibly compensated by steeper economic growth and infrastructure investments by the European Union. The overall picture remains valid though: for total PG consumption, agricultural use is vital.

The gypsum industry should have substantial interest in new gypsum sources, especially owing to market concentration. Two major disadvantages of PG were identified: the potential lack of public acceptance because of the potential minimum radionuclide content-mainly valid for board producers - and the negative effect of impurities on product quality. Other factors with potential negative impact are implementation and process quality, necessity for primary treatment, grain size and form, $\mathrm{pH}$-value and public acceptance. Due to the lack of gypsum dilution, the board industry worries about public acceptance. Grain size and form cause troubles in calcining, therefore additional process steps or mixing with natural gypsum would be necessary to meet strength requirements. Adapting the fertilizer 
production process has allowed the successful use of PG derived from igneous sources though.

The lower gypsum content in cement lessens the impact of radioactivity, hence public acceptance is easier to achieve. Grain size and form also have a less significant impact, impurities are the main concern. Occasionally, PG is already applied in cement production. Unfortunately, many cement plants only process about $50,000 t$ of gypsum annually, significantly less than produced in fertilizer plants.

As for agriculture, small grain size improves solubility and is therefore a positive factor. Since food safety is of major interest, heavy metal concentration and radioactivity cause concern. Monitoring the effects of PG application will be necessary.

Considering the above mentioned points, it is obvious that only one application alone cannot uptake the entity of PG produced in ESEE or Europe overall. A combination of cement production and agricultural applications are most likely to be accepted and technically feasible.

Furthermore, the technical and economic feasibility of REE extraction and other precious elements should be taken into consideration. Since the REE content of sedimentary phosphates is generally lower than that of igneous phosphates, the degree of extractability is crucial. Recent mine openings and developments in extraction technology may indicate volatile REE prices in the future. This should be considered in feasibility and economic calculations. The market for radium is very limited, assumptions concerning the price are therefore difficult to make, so are the costs for the concentration process. There is a high demand for radium from pharmaceutical companies and laboratories though.

Acknowledgements. The EIT Raw Materials supported this work under the framework of the "RaPhoSafe" project.

Funding. Open access funding provided by Montanuniversität Leoben.

Open Access This article is distributed under the terms of the Creative Commons Attribution 4.0 International License (http://creativecommons. org/licenses/by/4.0/), which permits unrestricted use, distribution, and reproduction in any medium, provided you give appropriate credit to the original author(s) and the source, provide a link to the Creative Commons license, and indicate if changes were made.

\section{References}

1. Tayibi, H.; Choura, M.; López, F. A.; Alguacil, F. J.; López-Delgado, A.: Environmental impact and management of phosphogypsum, Journal of environmental management 90 (2009), no. 8, pp 2377-2386

2. Reichl, C.; Schatz, M.; Zsak, G.: World mining data, Minerals Production, vol. 33, Vienna: Federal Ministry of Sustainability and Tourism, 2018

3. Rashad, A. M.: Phosphogypsum as a construction material, Journal of Cleaner Production 166 (2017), pp 732-743

4. International Trade Centre, Market Analysis and Research Section: Trade Map, www.trademap.org (05.11.2018)

5. Jasinski, S. M.: Phosphate rock, US Geological Survey mineral commodity summaries (2018), Washington, D.C.: USGS, 2018, pp 122-123
6. FAPRI: Total fertilizer use in the European Union from 2010 to 2025 , https://www.statistica.com/statistics/201464/total-eu-fertilizer-usefrom-2010/. (05.12.2018)

7. Alwast, H.: Supply of Gypsum to industry in the context of the "energy turnaround" in Europe: Prognos-Report (Multi-Client-Study), Ashtrans Europe, Berlin, 2014, http://ashtrans.eu/onewebmedia/9 \%20\%20\%20\%20\%20Prognos\%20study\%20Ashtrans_HAL_FINAL. pdf (11.11.2018)

8. EUROSTAT: Prodcom: NACE Rev. 2, https://ec.europa.eu/eurostat/ de/web/prodcom/data/database (11.11.2018)

9. Mohammed, S.; Safiullah, O.: Optimization of the $\mathrm{SO}_{3}$ content of an Algerian Portland cement: Study on the effect of various amounts of gypsum on cement properties, Construction and Building Materials 164 (2018), pp 362-370

10. Soroka, I.; Abayneh, M.: Effect of gypsum on properties and internal structure of PC paste, Cement and Concrete Research 16 (1986), Nr. 4, pp 495-504

11. ÖNORM EN197-1: Zement - Teil 1: Zusammensetzung, Anforderungen und Konformitätskriterien von Normalzement, Wien: Österreichisches Normungsinstitut, 2011

12. Pereda, A.: European cement market: limited recovery; upgrade CRH (2017), http://linkback.morganstanley.com/web/sendlink/ webapp/f/ghfhbegq-3psp-g002-b436-005056013501?store $=0 \& d=$ UwBSZXNIYXJjaF9NUwA5NTM1NjU3MC04MzU3LTEXZTctOTEwN i0xZmZkMTBjMDFjYzc\%3D\&user=dgnrri07xtbhq-2\&_gda_= 1631561949_2e5f3f534d156a82bc538b27bbaa1a8e (11.11.2018)

13. Rutherford, P. M.; Dudas, M. J.; Samek, R. A.: Environmental impacts of phosphogypsum, The Science of the total environment 149 (1994), 1-2, pp 1-38

14. Sterling, S. M.; Ducharne, A.; Polcher, J.: The impact of global landcover change on the terrestrial water cycle, Nature Climate Change 3 (2013), pp 385-390

15. Vautard, R.; Gobiet, A.; Sobolowski, S.; Kjellström, E.; Stegehuis A.; Watkiss, P.; Mendlik, T.; Landgren, O.; Nikulin, G.; Teichmann, C.; Jacob, D.: The European climate under a $2{ }^{\circ} \mathrm{C}$ global warming, Environmental Research Letters 9 (2014), Nr. 3, p 34006

16. Abril, J.-M.; García-Tenorio, R.; Enamorado, S. M.; Hurtado, M. D.; Andreu, L.; Delgado, A.: The cumulative effect of three decades of phosphogypsum amendments in reclaimed marsh soils from SW Spain: (226) Ra, (238) U and Cd contents in soils and tomato fruit, The science of the total environment 403 (2008), 1-3, pp 80-88

17. Papastefanou, C.; Stoulos, S.; loannidou, A.; Manolopoulou, M.: The application of phosphogypsum in agriculture and the radiological impact, Journal of environmental radioactivity 89 (2006), no. 2, pp 188-198

18. Inagaki, T. M.; Moraes Sá, J. C. de; Caires, E. F.; Gonçalves, D. R. P. Lime and gypsum application increases biological activity, carbon pools, and agronomic productivity in highly weathered soil, Agriculture, Ecosystems \& Environment 231 (2016), pp 156-165

19. Zhao, Y.; Wang, S.; Li, Y.; Liu, J.; Zhuo, Y.; Zhang, W.; Wang, J.; $\mathrm{Xu}$, L.: Long-term performance of flue gas desulfurization gypsum in a large-scale application in a saline-alkali wasteland in northwest China, Agriculture, Ecosystems \& Environment 261 (2018), pp 115-124

20. Li, J.; Wang, J.: Integrated life cycle assessment of improving saline-sodic soil with flue gas desulfurization gypsum, Journal of Cleaner Production 202 (2018), pp 332-341

21. ESBN: The European Soil Database distribution version 2.0, European Commision and European Soil Bureau Network, CD-ROM, EUR 19945 EN, 2004

22. Panagos, P.: The European soil database, GEO: connexion 5 (2006), Nr. 7, pp 32-33

Publisher's Note. Springer Nature remains neutral with regard to jurisdictional claims in published maps and institutional affiliations. 